\title{
Prevalence and etiological agents of subclinical mastitis at the end of lactation in nine dairy herds in North-East Poland
}

\author{
M. Sztachańska ${ }^{1}$, W. Barański ${ }^{1}$, T. Janowski ${ }^{1}$, J. Pogorzelska ${ }^{2}$, S. Zduńczyk ${ }^{1}$ \\ ${ }^{1}$ Department of Animal Reproduction with Clinic, Faculty of Veterinary Medicine, \\ University of Warmia and Mazury, Oczapowskiego 14, 10-719 Olsztyn, Poland \\ ${ }^{2}$ Department of Cattle Breeding and Milk Quality Evaluation, Faculty of Animal Bioengineering, \\ University of Warmia and Mazury, Oczapowskiego 5, 10-719 Olsztyn, Poland
}

\begin{abstract}
The aim of this study was to evaluate the prevalence and etiological agents of subclinical mastitis at the end of lactation in nine dairy herds in North-East Poland. In total, 387 Polish HF were involved in the study. The diagnosis of mastitis was performed on the basis of clinical examination of the udder, macroscopic evaluation of milk, determination of somatic cell count and bacteriological examination of milk. Subclinical mastitis was found in an average of $36.7 \%$ (range from $21.0 \%$ to $53.1 \%$ ) of cows and of $15.7 \%$ (range from $9.6 \%$ to $25.2 \%$ ) of quarters. Coagulase negative staphylococci (CNS; $31.6 \%$ of quarters), Streptococcus (Str.) agalactiae (15.6\% of quarters), Staphylococcus (Staph.) aureus (12.1\% of quarters) and fungi $(12.2 \%$ of quarters) were most frequently isolated from subclinical mastitis. Etiological agents of subclinical mastitis differed strongly between herds. The results of this study showed that the incidence of subclinical mastitis at the end of lactation in dairy herds in North-East Poland is high. CNS were the most frequently isolated from subclinical mastitis cases, however mastitis caused by the contagious pathogens Str. agalactiae and Staph. aureus is still a problem. The fungal infections of the mammary gland also play an important role.
\end{abstract}

Key words: cows, drying off, subclinical mastitis, etiological agents

\section{Introduction}

Mastitis is characterized by an inflammation in one or more quarters of the udder and can be either clinical or subclinical (International Dairy Federation 1987). Clinical cases give rise to visible symptoms such as swelling, heat, pain in the affected quarters or clots and discoloration of the secretion. Cows with subclini- cal mastitis do not show a visible udder inflammation and can be diagnosed by somatic cell count (SCC) and by detection of the presence of pathogens (Malinowski and Kłosowska 2002, Pyörälä 2003, Hamann 2005). Subclinical mastitis is 15 to 40 times more prevalent than the clinical form of mastitis (Seegers et al. 2003). 
Mastitis is the most costly disease in dairy production, due to its high incidence and losses. Losses caused by clinical mastitis include reduced milk yield and quality, costs of veterinary care, discarded milk and shortening of productive life (Kossaibati and Esselemont 1997, Nielsen et al. 2010, Hogeveen et al. 2011). However, the majority of the economic losses caused by subclinical mastitis are due to reduced milk production (Seegers et al. 2003, Huijps et al. 2008). Milk and dairy products made from mastitic milk may cause foodborne diseases, infections or intoxications (Twardoń et al. 2005, Malinowski and Gajewski 2009).

Several causative agents have been implicated in mastitis in dairy cows including bacterial, mycoplasmal and yeast pathogens. Streptococci, CNS and Staph. aureus are the most frequently isolated pathogens from subclinical cow mastitis. Infections caused by yeasts are also important (Malinowski et al. 1993, Gianneechini et al. 2002, Barański et al. 2008, Wawron et al. 2010). However, in many countries, including Poland, changes in the relative and absolute importance of the main mastitis pathogens have been observed over time, probably because of marked changes in the dairy industry (Myllys et al. 1998, Pitkälä et al. 2004, Malinowski et al. 2006).

Efficacious treatment is an important component of any mastitis control program. The clinical cases in lactating cows should be treated promptly with an appropriate intramammary antibiotic. In severe cases systemic antibiotic may be used, either alone or in combination with an intramammary infusion (Malinowski 1997, Owens et al. 1997). The most effective time to treat subclinical mastitis is at drying off. Dry cow therapy with a long-acting intramammary preparation serves to eliminate subclinical infections present at the end of lactation and to prevent many new dry period infections (Osteras et al. 1994, Malinowski 1997, 2000). Treatment of all cows at drying off, independent of their infectious stage (blanket or total therapy) continues to be the standard procedure in most countries, except the Nordic European countries and the Netherlands. Most herds have been shown to benefit from blanket therapy at drying off with an antimicrobial infusion (Dingwell et al. 2003, Robert et al. 2006).

However, routine treatment of all cows has been questioned because of global concerns for developing antimicrobial drug resistance. Overuse of antibiotics in veterinary medicine is considered one of the main factors responsible for the emergence of antibiotic resistance in bacteria. The majority of antibiotics used in dairy herds are related to udder health, mainly as dry cow products (de Briyne et al. 2014). Recently, selective dry cow therapy has been recommended (van Werven 2014). In this strategy, only cows or quarters assumed to be infected are treated. Studies have shown (Halasa et al. 2009) that cure rates were no different from blanket dry cow therapy when selective dry cow therapy was used, and selective dry cow therapy successfully eliminated intramammary infections to the same degree as did blanket dry cow therapy (Cameron et al. 2014). In the Netherlands following legislation that antimicrobials should no longer be used to prevent infections, selective dry cow treatment was implemented on January $1^{\text {st }} 2014$ (van Werven 2014).

An alternative to the use of dry cow therapy in cows with uninfected quarters is to apply a nonantibiotic teat sealer (either internal or external) (Berry and Hillerton 2002, Huxley et al. 2002, Lim et al. 2007). In cows with infected quarters at drying off these sealers can be used in combination with a long-acting antibiotic infusion to achieve elimination of the existing infections (Godden et al. 2003, Bradley et al. 2010). Therefore, knowledge of the health status of the mammary gland at the end of lactation has a significant impact on the choice of the best strategy for the treatment of existing subclinical infections and prevention of new intramammary infections during the dry period.

There are only a few studies about the incidence of subclinical mastitis before drying off in Poland (Malinowski et al. 1993, Barański et al. 2008). Thus, the aim of this study was to evaluate the prevalence and etiological agents of subclinical mastitis at the end of lactation in nine dairy herds in North-East Poland.

\section{Materials and Methods}

The study was carried out on 387 Polish HF cows from nine dairy herds in North-East Poland. Herd size ranged from 21 to 100 milking cows. All herds were housed in a loose housing barn and fed total mixed ration based on grass silage, maize silage and concentrate. The cows were milked twice daily in a milking parlor. The average milk yield ranged from 6000 to 80001 per year. Blanket dry cow therapy was implemented in all herds.

The study was conducted according to good veterinary practice. The diagnosis of mastitis was performed on the basis of clinical examination of the udder, macroscopic evaluation of milk, determination of somatic cell count and bacteriological examination of milk. None of the cows suffered from clinical mastitis. Double milk samples were collected aseptically from 1538 quarters a week before drying off. Ten quarters were atrophic. The teats were cleaned and the first few streams were discarded. The teats were then dipped in disinfectant and the teat ends were wiped with 
Table 1. Prevalence of subclinical mastitis in nine dairy herds.

\begin{tabular}{|c|c|c|c|c|c|c|}
\hline \multirow{3}{*}{ Herd } & \multicolumn{3}{|c|}{ Cows } & \multicolumn{3}{|c|}{ Quarters } \\
\hline & \multirow{2}{*}{$\begin{array}{l}\text { number of examined } \\
\text { cows }\end{array}$} & \multicolumn{2}{|c|}{ subclinical mastitis } & \multirow{2}{*}{$\begin{array}{l}\text { number of examined } \\
\text { quarters }\end{array}$} & \multicolumn{2}{|c|}{ subclinical mastitis } \\
\hline & & $\mathrm{n}$ & $\%$ & & $\mathrm{n}$ & $\%$ \\
\hline A & 32 & 17 & $53.1^{\mathrm{a}, \mathrm{b}}$ & 127 & 32 & $25.2^{\mathrm{a}}$ \\
\hline B & 57 & 15 & $26.3^{c}$ & 227 & 23 & $10.1^{\mathrm{b}, \mathrm{c}}$ \\
\hline $\mathrm{C}$ & 45 & 23 & $51.1^{\mathrm{a}, \mathrm{b}}$ & 179 & 30 & $16.8^{\mathrm{a}, \mathrm{b}}$ \\
\hline $\mathrm{D}$ & 41 & 19 & $46.3^{\mathrm{a}, \mathrm{b}}$ & 163 & 38 & $23.3^{\mathrm{a}}$ \\
\hline $\mathrm{E}$ & 36 & 13 & $36.1^{\mathrm{b}, \mathrm{c}}$ & 143 & 29 & $20.3^{\mathrm{a}, \mathrm{b}}$ \\
\hline $\mathrm{F}$ & 25 & 11 & $44.0^{\mathrm{b}, \mathrm{c}}$ & 100 & 19 & $19.0^{\mathrm{a}, \mathrm{b}}$ \\
\hline$G$ & 21 & 10 & $47.6^{\mathrm{b}, \mathrm{c}}$ & 82 & 18 & $22.0^{\mathrm{a}, \mathrm{b}}$ \\
\hline $\mathrm{H}$ & 30 & 9 & $30.0^{\mathrm{b}, \mathrm{c}}$ & 120 & 14 & $11.7^{\mathrm{b}, \mathrm{c}}$ \\
\hline I & 100 & 25 & $21.0^{\mathrm{c}}$ & 397 & 38 & $9.6^{c}$ \\
\hline Total & 387 & 142 & 36.7 & 1538 & 241 & 15.7 \\
\hline
\end{tabular}

a, b, c - values within the same column with different superscript letters differ significantly at $\mathrm{p}<0.05$

Table 2. Microorganism (\%) isolated from subclinical mastitis in nine dairy herds at the end of lactation.

\begin{tabular}{|c|c|c|c|c|c|c|c|c|c|c|c|}
\hline \multirow[b]{2}{*}{ Herd } & \multicolumn{11}{|c|}{ Microorganisms $\%$} \\
\hline & $\begin{array}{l}\text { Staph. } \\
\text { aureus }\end{array}$ & CNS & $\begin{array}{c}\text { Str. } \\
\text { agalactiae }\end{array}$ & $\begin{array}{c}\text { Str. } \\
\text { dysgala- } \\
\text { ctiae }\end{array}$ & $\begin{array}{l}\text { Str. } \\
\text { uberis }\end{array}$ & $\begin{array}{l}\text { Other } \\
\text { Str. }\end{array}$ & $\begin{array}{c}\mathrm{T} . \\
\text { pyogenes }\end{array}$ & E. coli & C. bovis & Fungi & $\begin{array}{l}\text { No } \\
\text { growth }\end{array}$ \\
\hline A & 15.5 & 15.6 & 12.5 & 0 & 15.6 & 0 & 0 & 9.4 & 9.4 & 25.0 & 0 \\
\hline B & 13.0 & 60.9 & 8.7 & 0 & 8.7 & 0 & 0 & 0 & 0 & 0 & 8.7 \\
\hline $\mathrm{C}$ & 13.3 & 16.7 & 23.3 & 0 & 6.7 & 0 & 0 & 3.3 & 0 & 23.3 & 20.0 \\
\hline $\mathrm{D}$ & 13.1 & 34.2 & 7.9 & 0 & 23.7 & 0 & 0 & 10.5 & 7.9 & 7.9 & 2.6 \\
\hline $\mathrm{E}$ & 0 & 68.9 & 13.8 & 0 & 6.9 & 10.3 & 3.4 & 0 & 10.3 & 10.3 & 6.9 \\
\hline $\mathrm{F}$ & 0 & 15.8 & 10.5 & 10.5 & 0 & 10.5 & 0 & 10.5 & 10.5 & 21.0 & 15.8 \\
\hline $\mathrm{G}$ & 5.5 & 11.1 & 27.8 & 11.1 & 11.1 & 5.5 & 0 & 0 & 0 & 22.2 & 5.5 \\
\hline $\mathrm{H}$ & 35.7 & 43.0 & 7.1 & 0 & 0 & 0 & 0 & 7.1 & 0 & 0 & 7.1 \\
\hline $\mathrm{I}$ & 13.1 & 18.4 & 28.9 & 5.3 & 0 & 2.6 & 0 & 0 & 10.5 & 0 & 31.6 \\
\hline Total & 12.1 & 31.6 & 15.6 & 2.9 & 8.1 & 3.2 & 0.4 & 4.5 & 5.4 & 12.2 & 10.9 \\
\hline
\end{tabular}

Percentages do not total 100 as some quarters had mixed infection with two pathogens.

alcohol swabs and allowed to dry. $10 \mathrm{ml}$ of the secretion was then collected into sterile tubes. The samples were cooled and immediately transported to the laboratory. SCC was measured with BactoCount IBm (Bentley, USA). Bacteriological examinations were performed according to commonly accepted rules (Malinowski and Kołosowska 2002). Briefly, $10 \mu \mathrm{l}$ of milk were cultivated on Blood Agar Base (bioMlrieux Poland), Mac Conkey Agar (BTL, Poland), Mueller-Hinton Agar (BTL, Poland) and Edwards Medium (Oxoid Ltd, England). Plates were incubated at $37^{\circ} \mathrm{C}$ and read 24 and 48 hours later. Bacteria were identified by their gross colony morphology and by Gram staining. Detailed identification of isolated bacteria was performed using API tests (bioMeieux Poland). Sabouraud Dextrose Agar (bioMlrieux, Poland) was used for isolation of fungi. Incubation took 5 days and $1 \mathrm{ml}$ of milk was used. Subclinical mastitis was diagnosed in a quarter, when clinical signs were not present and the SCC was higher than $400000 / \mathrm{ml}$ with or without positive isolation of udder pathogens.

Statistical analyses were performed using GraphPad PRISM 6.0 (GraphPad Software Inc., San Diego, $\mathrm{Ca}, \mathrm{USA})$. Differences in incidence of mastitis among herds were statistically analyzed using Yates corrected Ch-square test. The level of significance was set at $\mathrm{p}<0.05$. 


\section{Results}

Prevalence of subclinical mastitis at the end of lactation is presented in Table 1. The elevation of SCC above $400000 / \mathrm{ml}$ was found in an average of $36.7 \%$ of cows and of $15.7 \%$ of quarters. The incidence of subclinical mastitis varied among herds from $21.0 \%$ to $53.1 \%$ cows, and from $9.6 \%$ to $25.2 \%$ quarters, respectively. The differences in incidence of subclinical mastitis in cows and quarters among herds were partially statistically significant $(\mathrm{p}<0.05)$. Microorganisms isolated from subclinical mastitis are presented in Table 2. Bacteria or fungi were isolated from $89.1 \%$ of quarters with subclinical mastitis, $10.9 \%$ of samples from mastitis cases were culture negative. CNS (31.6\% of quarters), Str. agalactiae (15.6\% of quarters), Staph. aureus (12.1\% of quarters) and fungi (12.2\% of quarters) were most frequently isolated from subclinical mastitis. Etiological agents of subclinical mastitis differed between herds. In herd E subclinical mastitis were caused mainly by CNS, in herd A by fungi, whereas in herd I the predominant pathogen was Str. agalactiae.

\section{Discussion}

The presence of subclinical mastitis before drying off can have profound effects on cow health and productivity after calving. There is a high risk that subclinical cases will become clinical after calving (Green et al. 2002).

Studies on the prevalence of subclinical mastitis in Polish dairy cows before drying off are limited. Malinowski et al. (1993) found subclinical mastitis in $22.6 \%$ of quarters, Barański et al. (2008) reported $38.5 \%$ of cows and $12.6 \%$ of quarters infected before drying off. In the present study, $36.7 \%$ of cows and $15.7 \%$ of quarters were diagnosed with subclinical mastitis at the end of lactation. The prevalence of subclinical mastitis before drying off was higher in other studies from the UK (34.5\% of quarters) and the USA (33\% of quarters) (Godden et al. 2003, Huxley et al. 2002). There was a large variation in the prevalence of subclinical mastitis at drying off between herds (range from $21.0 \%$ to $53.1 \%$ of cows and from $9.6 \%$ to $25.2 \%$ of quarters). This may be explained by the difference in milking management and environmental factors between the herds.

Over 137 different organisms have been identified as being causative agents of bovine mastitis, including bacteria, viruses, mycoplasma, yeasts and algae (Watts 1988). In the present study, most of the mastitis cases $(31.6 \%)$ were caused by CNS. Similar results were reported from Poland by Malinowski et al.
(2006), Barański et al. (2008) and Bochniarz et al. (2013). CNS have become the predominant pathogen isolated from subclinical bovine mastitis in many countries, and could therefore be described as emerging mastitis pathogens (Myllys et al. 1998, Pyörälä and Taponen 2009). In the study from Germany, 35\% of quarters with subclinical mastitis harbored CNS (Tenhagen et al. 2006). In Finland, CNS were isolated from $50 \%$ of the quarters positive for bacterial growth (Pitkälä et al. 2004).

Generally, the percentage of particular etiological agents of mastitis has changed during recent decades in many countries. A decrease in frequency of mastitis caused by Str. agalactiae as an effect of introduction of mastitis control programs has been observed (Myllys et al. 1998, Pitkälä et al. 2004, Hillerton and Berry 2005). In Poland, a decrease in Str. agalactiae infections was reported by Malinowski et al. (2006). However, in the present study Str. agalactiae was found in an average of $15.6 \%$ (range $7.9-28.9 \%$ ) of quarters with subclinical mastitis. The high incidence of Str. agalactiae indicates the low efficacy of dry cow therapy in some herds.

Staph. aureus is permanently present in dairy herds. In our study, this pathogen was isolated from $12.1 \%$ of quarters with subclinical mastitis. Similar results were obtained by Malinowski et al. (2006), who found Staph. aureus in $8.6 \%$ cases of clinical and subclinical mastitis in the western part of Poland. This is in accordance with data from other countries (Gianneechini et al. 2002, Pitkälä et al. 2004, Tenhagen et al. 2006).

An increasing problem is mastitis caused by fungi. In our study the presence of fungi was found in $12.2 \%$ of quarters with subclinical mastitis. Krukowski et al. (2000) isolated fungi from $9.6 \%$ of milk samples from cows with mastitis, Wawron et al. (2010) showed that fungi constituted $7.07 \%$ of all etiological agents of mastitis. In other studies the frequency of mastitis caused by fungi was lower (Malinowski et al. 2006). Fungal infections are associated mainly with prolonged intramammary administration of antibiotics, improper conditions in cow barns and poor milking hygiene (Malinowski 1997, Wawron et al. 2010).

The results of our study showed that the incidence of subclinical mastitis at the end of lactation in dairy herds in North-East Poland is high. CNS were the most frequently isolated from subclinical mastitis cases; however, mastitis caused by the contagious pathogens Str. agalactiae and Staph. aureus is still a problem. Fungal infections of the mammary gland also play an important role. 


\section{References}

Barański W, Raś M, Janowski T, Zduńczyk S, Dewulf J, de Kruif A, de Vliegher S, Opsomer G (2008) Udder pathogens isolated from milk of cows before drying off and their antibiotic sensitivity. Med Weter 64: 301-305.

Berry EA, Hillerton JE (2002) The effect of an intramammary teat seal on new intramammary infections. J Dairy Sci 85: 2512-2520.

Bochniarz M, Wawron W, Szczubiał M (2013) Coagulase-negative staphylococci (CNS) as an aetiological factor of mastitis in cows. Pol J Vet Sci 16: 487-492.

Bradley AJ, Breen JE, Payne B, Williams P, Green MJ (2010) The use of a cephalonium containing dry cow therapy and an internal teat sealant, both alone and in combination. J Dairy Sci 93: 1566-1577.

Cameron M, McKenna SL, MacDonald KA, Dohoo IR, Roy JP, Keefe GP (2014) Evaluation of selective dry cow treatment following on-farm culture: risk of postcalving intramammary infection and clinical mastitis in the subsequent lactation. J Dairy Sci 97: 270-284.

De Briyne N, Atkinson J, Pokludovh L, Borriello SP (2014) Antibiotics used most commonly to treat animals in Europe. Vet Rec 175: 325.

Dingwell RT, Kelton DF, Leslie KE (2003) Management of the dry cow in control of peripartum disease and mastitis. Vet Clin North Am Food Anim Pract 19: 235-265

Gianneechini R, Concha C, Rivero R, Delucci I, Moreno Lopez J (2002) Occurrence of clinical and sub-clinical mastitis in dairy herds in the West Littoral Region in Uruguay. Acta Vet Scand 43: 221-230.

Godden S, Rapnicki P, Stewart S, Fetrow J, Johnson A, Bey R, Farnsworth R (2003) Effectiveness of an internal teat seal in the prevention of new intramammary infections during the dry and early-lactation periods in dairy cows when used with a dry cow intramammary antibiotic. J Dairy Sci 86: 3899-3911.

Green MJ, Green LE, Medley GF, Schukken YH, Bradley AJ (2002) Influence of dry period bacterial intramammary infection on clinical mastitis in dairy cows. J Dairy Sci 85: 2589-2599.

Halasa T, Nielen M, Whist AC, Østeras O (2009) Meta-analysis of dry cow management for dairy cattle. Part 2. Cure of existing intramammary infections. J Dairy Sci 92: 3150-3157.

Hamann J (2005) Diagnosis of mastitis and indicators of milk quality. In: Hogeveen $\mathrm{H}$ (ed) Mastitis in dairy production: Current knowledge and future solutions. Wageningen Academic Publishers, pp 82-90.

Hillerton JE, Berry EA (2005) Treating mastitis in the cow - a tradition or an archaism. J Appl Microbiol 98: 1250-1255.

Hogeveen H, Huijps K, Lam TJ (2011) Economic aspects of mastitis: new developments. N Z Vet- J 59: 16-23.

Huijps K, Lam TJ. Hogeveen H (2008) Costs of mastitis: facts and perception. J Dairy Res 75: 113-120.

Huxley JN, Green MJ, Green LE, Bradley AJ (2002) Evaluation of the efficacy of an internal teat sealer during the dry period J Dairy Sci 85: 551-561.

International Dairy Federation (1987) Bovine mastitis: definition and guidelines for diagnosis. Bulletin No 211, IDF, Brussels, Belgium.
Kossaibati MA, Esslemont R.J (1997) The costs of production diseases in dairy herds in England. Vet J 154: 41-51.

Krukowski H, Tietze M, Majewski T, Różański P (2000) Survey of yeast mastitis in dairy herds of small-type farms in the Lublin region, Poland. Mycopathologia 150: 5-7.

Lim GH, Leslie KE, Kelton DF, Duffield TF, Timms LL, Dingwell RT (2007) Adherence and efficacy of an external teat sealant to prevent new intramammary infections in the dry period. J Dairy Sci 90: 1289-1300.

Malinowski E (1997) Przyczyny, leczenie i zapobieganie mastitis u krów. 1st ed., Wyd. PIWet, Puławy.

Malinowski E (2000) Mastitis prophylaxis and treatment during dry period - advantages and threats. Med Weter 56: 759-763.

Malinowski E, Gajewski Z (2009) Characteristics of cows mastitis caused by human foodborne pathogens. Życie Wet 84: 290-294.

Malinowski E, Kłossowska A (2002) Diagnostyka zakażeń wymienia. Wyd. PIWet, Puławy.

Malinowski E, Kłossowska A, Markiewicz H, Szalbierz M, Biegała T (1993) Therapy and prophylactic measures of mastitis in cows in dry period by means of different drugs. Med Weter 49: 400-402.

Malinowski E, Lassa H, Kłossowska A, Smulski S, Markiewicz H, Kaczmarowski M (2006) Etiological agents of dairy cows' mastitis in western part of Poland. Pol J Vet Sci 9: 191-194.

Myllys V, Asplund K, Brofeldt E, Hirvelä-Koski V, Honkanen-Buzalski T, Junttila J, Kulkas L, Myllykangas O, Niskanen M, Saloniemi H, Sandholm M, Saranpää T (1998) Bovine mastitis in Finland in 1988 and 1995 - changes in prevalence and antimicrobial resistance. Acta Vet Scand 39: 119-126.

Nielsen C, Østergaard S, Emanuelson U, Andersson H, Ber-glund B, Strandberg E (2010) Economic consequenc-es of mastitis and withdrawal of milk with high somatic cell count in Swedish dairy herds. Animal 4: $1758-1770$.

Osteras O, Aursjo J, Gjul GG, Jorstad A (1994) Effect of dry-cow therapy on subclinical mastitis - an evaluation of long-acting and short-acting intramammaria. Zentralbl Veterinarmed B 41: 529-540.

Owens WE, Ray CH, Watts JL, Yancey RJ (1997) Comparison of success of antibiotic therapy during lactation and results of antimicrobial susceptibility test for bovine mastitis. J Dairy Sci 80: 313-317.

Pitkälä A, Haveri $M$, Pyörälä $S$, Myllys V, Honkanen-Buzalski T (2004) Bovine mastitis in Finland 2001- prevalence, distribution of bacteria, and antimicrobial resistance. J Dairy Sci 87: 2433-2441.

Pyörälä S (2003) Indicators of inflammation in the diagnosis of mastitis. Vet Res 34: 565-578.

Pyörälä S, Taponen S (2009) Coagulase-negative staphylococci - emerging mastitis pathogens. Vet Microbiol 134: 3-8.

Robert A, Seegers H, Bareille N (2006) Incidence of intramammary infections during the dry period without or with antibiotic treatment in dairy cows - a quantitative analysis of published data. Vet Res 37: 24 -48

Seegers H, Fourichon C, Beaudeau F (2003) Production effects related to mastitis and mastitis economics in dairy cattle herds. Vet Res 34: 475-491. 
Tenhagen BA, Koster G, Wallmann J, Heuwieser W (2006) Prevalence of mastitis pathogens and their resistance against antimicrobial agents in dairy cows in Brandenburg, Germany. J Dairy Sci 89: 2542-2551.

Twardoń J, Sobieszczańska B, Gonet A, Błaszkowska M (2005) Epidemiology of Shiga-like toxin - producing Escherichia coli strains (STEC). EJPAU 8: \#3 http://www.ejpau.media.pl/volume8/issue4/art-03.html
Van Werven T (2014): The use of antimicrobials in prevention and cure of mastitis. What is our responsibility. Proceed National Mastitis Council Regional Meeting, August 4-6, Ghent, pp 7-12.

Watts, LJ (1988): Etiological agents of bovine mastitis. Vet Microbiol 16: 41-66.

Wawron W, Bochniarz M, Piech T (2010) Yeast mastitis in dairy cows in the middle-eastern part of Poland. Bull Vet Inst Pulawy 54: 201-204. 